\title{
WEED INFESTATION OF SPRING BARLEY (Hordeum vulgare L.) DEPENDING ON THE COVER CROP AND WEED CONTROL METHOD
}

\author{
Dorota Gawęda, Marian Wesołowski, Cezary A. Kwiatkowski \\ Department of Herbology and Plant Cultivation Techniques, University of Life Sciences in Lublin \\ Akademicka 13, 20-950 Lublin, Poland \\ e-mail: dorota.gaweda@up.lublin.pl
}

Received: 07.09.2013

\begin{abstract}
The aim of this 3-year field study was to evaluate the effect of some stubble crops and weed control methods on the species composition, number and air-dry weight of weeds in a spring barley crop grown in short-term monoculture. The study was conducted in the period 2009-2011 at the Uhrusk Experimental Farm, on mixed rendzina soil classified as very good rye soil complex. It included stubble crops which were ploughed under in each year (control treatment without cover crop, white mustard, lacy phacelia, a mixture of legumes - narrow-leaf lupin + field pea) and 3 weed control methods used in spring barley crops (mechanical, mechanical and chemical, chemical weed control). Veronica persica was the weed species that occurred in greatest numbers in the spring barley crop sown after stubble crops. All cover crops reduced the numbers of Avena fatua which was the dominant species in the control treatment. Chemical as well as chemical and mechanical weed control significantly reduced the numbers of Avena fatua compared to the treatment where only double harrowing was used for weed control. The stubble crops did not reduce weed infestation of spring barley. Compared to the control treatment, the ploughing-in of white mustard and the mixture of legumes reduced the dry weight of weeds by 49.1 and $22.7 \%$, respectively. Mechanical weed management proved to be less effective in reducing the number and dry weight of weeds compared to the other weed control methods. A significant negative correlation was found between the dry weight of weeds in the spring barley crop and the dry weight of the ploughed-in white mustard cover crop under the conditions of chemical weed control as well as in the case of the mixture of legumes when complete mechanical and chemical weed control was used.
\end{abstract}

Key words: Hordeum vulgare, monoculture, weed infestation, stubble crop, weed control

\section{INTRODUCTION}

Spring barley belongs to plants that are sensitive to crop sequencing and responds with a distinct decrease in yield to the lack of crop rotation [1,2]. In such crop stands, increased weed infestation and compensation of troublesome weed species are frequently found, among others, which results in a deterioration of most crop and ear components and consequently in reduced yields $[3,4]$. Therefore, optimal agronomic solutions that will mitigate the negative effects of continuous cropping are constantly sought. One of such methods is the introduction of cover crops as plants that play a phytosanitary role, supplement mineral fertilization and improve soil organic matter balance. Cover crops are an environmentally-friendly method to reduce weed infestation in crops, irrespective of the cover plant [5-8]. Growing cover crops as green manure that is ploughed under, which improves the quality of the soil environment with relatively low investment, is gaining special importance $[9,10]$. The studies of some authors show that the ploughing-in of such crops before winter reduces weed infestation, increases cereal crop yields and is a more beneficial method for counteracting the negative effects of continuous cereal cropping compared to soil mulching with cover crops for the winter period $[9,11]$.

A hypothesis was formulated on the basis of the results of existing research that stubble crops ploughed in before winter, regardless of the weed control method, would compensate for the negative effects of growing spring barley after itself, thus contributing to reduced weed infestation of this crop plant. To verify this assumption, a study was conducted to evaluate the effects of some stubble crops and in-crop weed control methods on the species composition, number and air-dry weight of weeds in a spring barley crop grown in short-term monoculture.

\section{MATERIALS AND METHODS}

A field study was conducted during the period 2009-2011 at the Uhrusk Experimental Farm belonging 
to the University of Life Sciences in Lublin, on mixed rendzina soil classified as very good rye soil complex. The soil showed an alkaline $\mathrm{pH}(\mathrm{pH}$ in $1 \mathrm{~mol} \mathrm{KCl}=$ 7.5). It was characterized by very high availability of phosphorus (141.8 $\mathrm{mg} \mathrm{P} \times 1 \mathrm{~kg}$ of soil) and potassium (221.7 $\mathrm{mg} \mathrm{K} \times 1 \mathrm{~kg}$ of soil) as well as very low magnesium availability ( $19 \mathrm{mg} \mathrm{Mg} \times 1 \mathrm{~kg}$ of soil). The humus content was at a level of $1.7 \%$, whereas the content of fines in the $0-30 \mathrm{~cm}$ layer was $25.5 \%$.

The experiment was set up as a split-plot design, in three replicates. The sown area of the plot was $35 \mathrm{~m}^{2}$, while the harvested area was $24 \mathrm{~m}^{2}$. In the present experiment, spring barley cv. 'Tocada' was grown after itself. This field experiment was established in 2009 in a field after spring barley; after the barley crop was harvested, the stubble crops were sown and ploughed under.

Experimental factors:

I. Type of stubble crop:

- without cover crop (control treatment);

- white mustard (Sinapis alba L.);

- lacy phacelia (Phacelia tanacetifolia Benth.);

- mixture of legumes: narrow-leaf lupin ( $\mathrm{Lu}$ pinus angustifolius L.) + field pea (Pisum sativum L.).

II. Method of weed control in the spring barley crop:

- mechanical weed control (harrowing: at the cracking stage and at the 3-4 leaf stage);

- mechanical and chemical weed control (harrowing at the 3-4 leaf stage and herbicide application);

- chemical weed control (herbicide application).

In the plot without cover crop (control treatment), skimming + double harrowing were performed after the harvest of barley, while before winter ploughing was done to a depth of about $25 \mathrm{~cm}$. Each year, the stubble crops were sown in the second 10-day period of August. Tillage for cover crops involved single ploughing and pre-sowing tillage using a seedbed cultivator consisting of a spring-tine harrow and cage roller. Cover crops were sown in the following amounts: white mustard $15 \mathrm{~kg} \times \mathrm{ha}^{-1}$, lacy phacelia 10 $\mathrm{kg} \times \mathrm{ha}^{-1}$, the legume mixture: field pea $100 \mathrm{~kg} \times \mathrm{ha}^{-1}$ and narrow-leaf lupin $100 \mathrm{~kg} \times \mathrm{ha}^{-1}$.

The biomass of the stubble crops was determined at the end of October. Plants were collected from an area of $1 \mathrm{~m}^{2}$ in each plot and their air-dry weight was determined. Having been first cut, the cover crop biomass left in the plots was ploughed under to a depth of $25 \mathrm{~cm}$ before winter each year.

Pre-sowing tillage for barley included the following: harrowing and additional soil preparation using a seedbed cultivator consisting of a spring-tine harrow and cage roller. Before sowing, seeds were dressed with the seed dressing Oxafun T 75 DS/WS (tiuram $375 \mathrm{~g} \times$ $\mathrm{kg}^{-1}+$ carboxin $375 \mathrm{~g} \times \mathrm{kg}^{-1}$ ) at a rate of $250 \mathrm{~g}$ per 100 $\mathrm{kg}$ of seed. Spring barley was sown in the first 10-day period of April at a rate of $140 \mathrm{~kg} \times \mathrm{ha}^{-1}$.

Fertilizer rates were determined on the basis of the nutritional requirements of the crop plant and soil nutrient availability. NPK rates were as follows: $\mathrm{N}-$ $40 \mathrm{~kg} \times \mathrm{ha}^{-1}$ (ammonium nitrate $\left.34.5 \%\right), \mathrm{P}-22 \mathrm{~kg} \times$ ha $^{-1}$ (superphosphate $40 \%$ ), $\mathrm{K}-33 \mathrm{~kg} \times \mathrm{ha}^{-1}$ (potassium salt $60 \%$ ). In the treatments with chemical weed control as well as with mechanical and chemical weed control, the following herbicides were applied at the beginning of the tillering stage (BBCH 21): Chwastox Turbo $340 \mathrm{SL}$ (MCPA $300 \mathrm{~g} \times \mathrm{l}^{-1}+$ dicamba $40 \mathrm{~g} \times$ $\mathrm{l}^{-1}$ ) at a rate of $21 \times \mathrm{ha}^{-1}+$ Puma Uniwersal $069 \mathrm{EW}$ (fenoxaprop-P-ethyl $69 \mathrm{~g} \times \mathrm{l}^{-1}$ ) at a rate of $11 \times \mathrm{ha}^{-1}$. In all the experimental treatments, the growth retard-

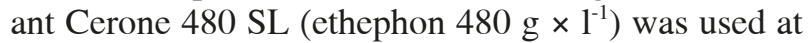
a rate of $11 \times \mathrm{ha}^{-1}$ at the 2 nd node stage (BBCH 32). At the beginning of stem elongation (BBCH 30), the fungicide Alert $375 \mathrm{SC}$ (flusilazole $125 \mathrm{~g} \times \mathrm{l}^{-1}+$ car-

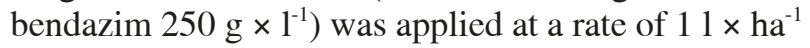
across the whole experiment.

Weed infestation in the crop was determined by the dry-weight-rank method at the beginning of the stem elongation stage (BBCH 31). The botanical (species) composition of weeds as well as their density and dry weight were determined in $1 \mathrm{~m} \times 0.5 \mathrm{~m}$ sampling areas in two randomly selected points of each plot.

The results were statistically analysed by analysis of variance, while the significance of differences was estimated by Tukey's test (at a significance level of 0.05).

Throughout the study period, the mean air temperature during the growth period of spring barley (IV-VIII) was higher than the long-term mean by, respectively, $0.7^{\circ} \mathrm{C}$ in $2009,1.9^{\circ} \mathrm{C}$ in 2010 , and $1.5^{\circ} \mathrm{C}$ in 2011. The air temperature in individual months during the period 2009-2011 was generally higher than the long-term average temperature. A lower temperature was recorded only in May (by $0.5^{\circ} \mathrm{C}$ ) and in June (by $0.2^{\circ} \mathrm{C}$ ) in 2009 (Table 1 ).

In all study years, the total rainfall during the growth period of spring barley (IV-VIII) much exceeded the long-term mean by, respectively, $45.5 \mathrm{~mm}$ in $2009,108.5 \mathrm{~mm}$ in 2010, and $40.2 \mathrm{~mm}$ in 2011 . Throughout the experiment duration, a lower amount of rainfall was recorded at the time when spring barley was sown (the first 10-day period of April) compared to the long-term average for this month. In 2009 this difference was as much as $12.1 \mathrm{~mm}$. Rainfall lower than the longterm mean was also recorded in July and August 2009, June and July 2010 as well as in May and August 2011. Taking into account particular months of the growing season, the most abundant rainfall was recorded in June 2009, May 2010, and July 2011 (Table 1). 
Table 1

Mean monthly air temperatures and total rainfall in 2009-2011 compared to the long-term mean in 1964-2011, according to the Uhrusk Meteorological Station

\begin{tabular}{|c|c|c|c|c|c|c|}
\hline \multirow{3}{*}{ Year } & \multicolumn{6}{|c|}{ Months } \\
\hline & IV & $\mathrm{V}$ & VI & VII & VIII & IV-VIII \\
\hline & \multicolumn{5}{|c|}{ Total rainfall (mm) } & Total \\
\hline 2009 & 27.0 & 81.5 & 169.3 & 42.7 & 60.0 & 380.5 \\
\hline 2010 & 34.4 & 150.5 & 72.6 & 57.5 & 128.5 & 443.5 \\
\hline 2011 & 34.5 & 42.0 & 87.4 & 147.2 & 64.1 & 375.2 \\
\hline \multirow[t]{2}{*}{ Mean for 1964-2011 } & 39.1 & 65.5 & 73.7 & 86.5 & 70.2 & 335.0 \\
\hline & \multicolumn{5}{|c|}{ Temperature $\left({ }^{\circ} \mathrm{C}\right)$} & Mean \\
\hline 2009 & 10.0 & 13.1 & 16.4 & 20.0 & 17.8 & 15.5 \\
\hline 2010 & 8.8 & 14.8 & 18.6 & 21.6 & 19.7 & 16.7 \\
\hline 2011 & 10.2 & 14.2 & 18.5 & 20.1 & 18.5 & 16.3 \\
\hline Mean for $1964-2011$ & 7.8 & 13.6 & 16.6 & 18.3 & 17.5 & 14.8 \\
\hline
\end{tabular}

\section{RESULTS}

The lacy phacelia cover crop caused a significant increase in the number of weeds per $1 \mathrm{~m}^{2}$ in the spring barley crop compared to the other experimental treatments (Table 2). Throughout the duration of the experiment, the highest number of weeds was recorded in the plots with ploughed-in lacy phacelia biomass.

Regardless of the cover crop, mechanical weed management involving only double harrowing proved to be the least effective in reducing the number of weeds (Table 2). The lowest number of weeds in the spring barley crop was found under the conditions of complete mechanical and chemical weed control. On average during the three-year study period, it reduced the number of weeds by $64.4 \%$ relative to the plot which was weeded only mechanically. A decrease in the number of weeds under the conditions of mechanical and chemical weed control in the crop was found in all years of the experiment, compared to the treatment in which only harrowing was used to control weeds, but in the second year of the study this decrease was not statistically proven.

A significant increase in the number of weeds was found after lacy phacelia under the conditions of mechanical and chemical weed control in the crop (Table 2). In the plots with mechanical weed removal alone, this increase was $69.5 \%$ compared to the treatment with ploughed-in white mustard biomass. In the crop where harrowing and herbicides were used for weed management, the number of weeds after lacy phacelia was nearly twice higher relative to the plots with white mustard and almost three times higher compared to the treatment without cover crop.

On average for the three-year study period, the ploughing-in of white mustard and legume mixture had a reducing effect on weed dry weight by 49.1 and $22.7 \%$, respectively, compared to the plots without cover crops (Table 3). A beneficial effect of white mustard and lupin/pea mixture, manifested by a reduction in the dry weight of weeds in the spring barley crop, was proven in the third year of the experiment.

Mechanical and chemical weed control as well as chemical weed control alone caused a decrease in weed weight by 88.3 and $87.0 \%$, respectively, compared to the plot which was weeded using only harrowing (Table 3 ). Weed management involving only double harrowing proved to be ineffective in reducing weed weight throughout the study period. But in the first year of the study, the differences in weed dry weight between individual treatments were not statistically significant.

The weed dry weight was proven to decrease after white mustard under the conditions of mechanical weed control in the crop (Table 3).

During the study period, a total of 31 weed species inhabited the spring barley crops, including 23 annual ones, while the other species were perennial weeds (Table 4). Avena fatua predominated in the treatment without cover crops. Veronica persica was the species that occurred in greatest numbers. All the stubble crops used reduced the numbers of Avena fat$u a$, which was dominant in the control treatment, and the numbers of the species Amaranthus retroflexus and Polygonum aviculare, which were found in quite large numbers. The ploughing-in of the white mustard and legume cover crops eliminated the species Cirsium arvense, which represented perennial weeds in greatest numbers in the control treatment. Among perennial weeds, Convolvulus arvensis was found to have the highest number of individuals after all the cover crops that had been ploughed under. The highest number of weed species was observed in the plots with ploughedin lacy phacelia biomass. In the other treatments, the number of species was at a similar level. 
Table 2

Number of weeds found in the spring barley crop depending on the cover crop and weed control method in 2009-2011 (in plants $\times \mathrm{m}^{-2}$ )

\begin{tabular}{|c|c|c|c|c|c|c|c|c|c|c|c|c|c|c|c|c|c|c|c|}
\hline \multirow[b]{2}{*}{ Year } & \multicolumn{4}{|c|}{ Without cover crop } & \multicolumn{4}{|c|}{ White mustard } & \multicolumn{4}{|c|}{ Lacy phacelia } & \multicolumn{4}{|c|}{ Legume mixture } & \multicolumn{3}{|c|}{ Mean } \\
\hline & $a^{*}$ & $\mathrm{~b}$ & $\mathrm{c}$ & $\underset{\widetilde{\varpi}}{\sum^{\varpi}}$ & $\mathrm{a}$ & $\mathrm{b}$ & c & $\sum_{\bar{\Xi}}^{\tilde{\Sigma}}$ & $\mathrm{a}$ & $\mathrm{b}$ & c & $\begin{array}{l}\text { चี } \\
\sum^{\oplus}\end{array}$ & $\mathrm{a}$ & $\mathrm{b}$ & $\mathrm{c}$ & $\begin{array}{l}\text { छี } \\
\sum^{\oplus}\end{array}$ & $\mathrm{a}$ & b & c \\
\hline 2009 & 17.0 & 4.7 & 9.0 & 10.2 & 21.0 & 7.7 & 15.3 & 14.7 & 27.3 & 18.7 & 15.7 & 20.6 & 22.3 & 13.3 & 12.3 & 16.0 & 21.9 & 11.1 & 13.1 \\
\hline 2010 & 6.0 & 3.0 & 5.3 & 4.8 & 13.0 & 6.7 & 13.3 & 11.0 & 11.0 & 13.0 & 11.3 & 11.8 & 10.7 & 11.7 & 9.0 & 10.5 & 10.2 & 8.6 & 9.7 \\
\hline 2011 & 61.0 & 8.7 & 13.7 & 27.8 & 23.0 & 9.7 & 12.0 & 14.9 & 58.3 & 14.3 & 14.7 & 29.1 & 52.7 & 3.7 & 5.3 & 20.6 & 48.8 & 9.1 & 11.4 \\
\hline Mean & 28.0 & 5.5 & 9.3 & 14.3 & 19.0 & 8.0 & 13.5 & 13.5 & 32.2 & 15.3 & 13.9 & 20.5 & 28.6 & 9.6 & 8.9 & 15.7 & 27.0 & 9.6 & 11.4 \\
\hline
\end{tabular}

$\mathrm{LSD}_{0.05}$ cover crop $=3.06$; weed control method $=2.41$; cover crop $\mathrm{x}$ weed control method $=6.82$;

cover crop $\mathrm{x}$ year $=6.82$; weed control method $\mathrm{x}$ year $=5.59$

* a: mechanical weed control

b: mechanical and chemical weed control

c: chemical weed control

Table 3

Dry weight of weeds found in the spring barley crop depending on the cover crop and weed control method in $2009-2011$ (in $\mathrm{g} \times \mathrm{m}^{-2}$ )

\begin{tabular}{|c|c|c|c|c|c|c|c|c|c|c|c|c|c|c|c|c|c|c|c|}
\hline \multirow[b]{2}{*}{ Year } & \multicolumn{4}{|c|}{ Without cover crop } & \multicolumn{4}{|c|}{ White mustard } & \multicolumn{4}{|c|}{ Lacy phacelia } & \multicolumn{4}{|c|}{ Legume mixture } & \multicolumn{3}{|c|}{ Mean } \\
\hline & $a^{*}$ & $\mathrm{~b}$ & $\mathrm{c}$ & 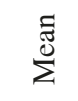 & a & $\mathrm{b}$ & $\mathrm{c}$ & 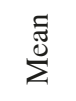 & a & $\mathrm{b}$ & $\mathrm{c}$ & $\underset{\Xi}{\tilde{\Xi}}$ & a & $\mathrm{b}$ & $\mathrm{c}$ & $\underset{\Xi \Xi}{\stackrel{\Xi}{\Sigma}}$ & a & $\mathrm{b}$ & $\mathrm{c}$ \\
\hline 2009 & 9.6 & 1.0 & 2.5 & 4.4 & 4.4 & 2.9 & 2.2 & 3.2 & 6.8 & 1.9 & 2.3 & 3.7 & 6.6 & 1.9 & 3.0 & 3.8 & 6.8 & 1.9 & 2.5 \\
\hline 2010 & 22.1 & 8.8 & 6.2 & 12.4 & 32.3 & 7.5 & 1.9 & 13.9 & 18.1 & 1.9 & 1.5 & 7.2 & 31.5 & 1.8 & 5.4 & 12.9 & 26.0 & 5.0 & 3.8 \\
\hline 2011 & 86.5 & 3.9 & 5.7 & 32.0 & 13.4 & 5.1 & 4.7 & 7.7 & 76.8 & 6.0 & 10.2 & 31.0 & 60.3 & 0.8 & 2.3 & 21.1 & 59.2 & 4.0 & 5.7 \\
\hline Mean & 39.4 & 4.6 & 4.8 & 16.3 & 16.7 & 5.2 & 2.9 & 8.3 & 33.9 & 3.3 & 4.7 & 14.0 & 32.8 & 1.5 & 3.6 & 12.6 & 30.7 & 3.6 & 4.0 \\
\hline $\operatorname{LSD}_{0.05}$ & & 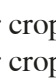 & & 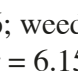 & 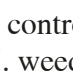 & 11 & & . & 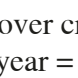 & $\begin{array}{l}\text { op x } \\
5.04\end{array}$ & eed & & & & & & & & \\
\hline
\end{tabular}

* a: mechanical weed control

b: mechanical and chemical weed control

c: chemical weed control

Avena fatua was the weed species that occurred in greatest numbers in the spring barley crop which was only mechanically weeded (Table 4). Veronica persica and Amaranthus retroflexus were also found in quite large numbers. The species Veronica persica dominated in the other experimental treatments. Chemical as well as mechanical and chemical weed control in the crops significantly reduced the number of Avena fatua individuals compared to the plot where only harrowing was used to control weeds. The application of herbicides and their combined use with mechanical weed removal eliminated Sonchus arvensis which occurred in greatest numbers among perennial species in the plots were weeds were only removed by double harrowing. The highest number of weed species was observed in the barley crop with mechanical weed control alone.

A significant negative correlation $(\mathrm{r}=-0.56)$ was found between the dry weight of the ploughed-in white mustard cover crop and the dry weight of weeds under the conditions of chemical weed management (Table 6). The statistical analysis also showed a significant negative correlation $(r=-0.51)$ between the dry weight of the mixture of legumes grown as a stubble crop and the weed dry weight when complete mechanical and chemical weed control was used. The highest biomass yield was obtained from the white mustard crops and from the legume mixture, while the lowest one from lacy phacelia (Table 5), which was reflected in the effects on weed infestation of the cereal crop investigated.

The correlation between cover crop dry weight and the number of weeds in the cereal crop subjected to weed control proved to be statistically insignificant (Table 7). However, a trend was found towards a lower number of weeds as a result cultivation of the cover crops with the highest yielding ability, white mustard and the mixture of legumes, and when chemical or chemical and mechanical weed control were used. 
Table 4

Weed species found in the spring barley crop depending on the cover crop and weed control method, in plants $\times \mathrm{m}^{-2}$ (mean for 2009-2011)

\begin{tabular}{|c|c|c|c|c|c|c|c|}
\hline \multirow{2}{*}{ Weed species } & \multicolumn{4}{|c|}{ Cover crop* } & \multicolumn{3}{|c|}{ Weed control method** } \\
\hline & A & $\mathrm{B}$ & $\mathrm{C}$ & $\mathrm{D}$ & a & $\mathrm{b}$ & $\mathrm{c}$ \\
\hline \multicolumn{8}{|c|}{ Annuals } \\
\hline Amaranthus retroflexus L. & 1.6 & 0.2 & 0.9 & 1.1 & 2.5 & 0.2 & 0.2 \\
\hline Anagallis arvensis $\mathrm{L}$. & 0.4 & 0.9 & 1.2 & 0.6 & 0.7 & 0.4 & 1.1 \\
\hline Avena fatua $\mathrm{L}$. & 4.5 & 2.1 & 3.2 & 3.6 & 9.5 & 0.2 & 0.3 \\
\hline Capsella bursa-pastoris (L.) Medik. & - & - & - & 0.0 & - & 0.0 & - \\
\hline Chenopodium album $\mathrm{L}$. & 0.5 & 0.2 & 0.4 & 0.3 & 1.1 & - & - \\
\hline Echinochloa crus-galli (L.) P. Beauv. & 0.3 & 0.4 & 0.6 & - & 0.7 & 0.1 & 0.2 \\
\hline Erodium cicutarium (L.) L’ Hér. & - & - & - & 0.1 & 0.1 & - & - \\
\hline Euphorbia helioscopia L. & - & $0.0 * * *$ & 0.1 & - & 0.0 & 0.1 & - \\
\hline Fallopia convolvulus (L.) Á. Löve & 0.4 & 0.9 & 0.7 & 1.1 & 1.3 & 0.6 & 0.5 \\
\hline Galium aparine $\mathrm{L}$. & 0.1 & 0.0 & 0.1 & 0.2 & 0.1 & 0.1 & 0.1 \\
\hline Geranium pusillum Burm. f. ex L. & 0.1 & 0.1 & 0.1 & - & 0.0 & 0.1 & 0.1 \\
\hline Lamium amplexicaule $\mathrm{L}$. & 0.1 & 0.1 & 0.1 & 0.1 & 0.0 & 0.1 & 0.2 \\
\hline Matricaria maritima ssp. inodora ( L.) Dostál & 0.1 & - & - & 0.0 & 0.0 & - & 0.1 \\
\hline Melandrium album (Mill.) Garcke & 0.3 & 0.6 & 1.0 & 1.1 & 1.1 & 0.5 & 0.6 \\
\hline Polygonum aviculare $\mathrm{L}$. & 1.3 & 0.7 & 1.1 & 0.6 & 1.8 & 0.4 & 0.5 \\
\hline Setaria viridis (L.) P. Beauv. & 0.1 & - & 0.1 & - & 0.1 & - & - \\
\hline Solanum nigrum L. Emend. Mill. & 0.2 & 0.3 & 0.2 & 0.2 & 0.3 & 0.0 & 0.2 \\
\hline Sonchus asper (L.) Hill & 0.4 & 0.5 & 1.2 & 0.6 & 1.4 & 0.4 & 0.2 \\
\hline Sonchus oleraceus L. & - & - & 0.1 & - & 0.1 & - & - \\
\hline Stellaria media (L.) Vill. & 0.1 & 0.6 & 0.9 & 0.4 & 0.6 & 0.6 & 0.4 \\
\hline Veronica persica Poir. & 2.2 & 3.9 & 5.5 & 4.5 & 3.6 & 3.8 & 4.7 \\
\hline Vicia hirsuta (L.) S.F. Gray & - & - & 0.1 & - & - & - & 0.1 \\
\hline Viola arvensis Murray & 0.2 & 0.7 & 0.7 & 0.3 & 0.5 & 0.5 & 0.4 \\
\hline \multicolumn{8}{|c|}{ Perennials } \\
\hline Artemisia vulgaris L. & - & 0.0 & 0.0 & - & - & - & 0.1 \\
\hline Cirsium arvense (L.) Scop. & 0.5 & - & 0.1 & - & 0.3 & 0.2 & - \\
\hline Convolvulus arvensis L. & 0.3 & 0.5 & 1.1 & 0.6 & 0.3 & 0.7 & 0.8 \\
\hline Elymus repens (L.) Gould & 0.3 & 0.3 & 0.3 & - & 0.1 & 0.3 & 0.3 \\
\hline Plantago intermedia Gilib. & - & 0.3 & 0.1 & 0.1 & 0.2 & 0.1 & 0.2 \\
\hline Plantago major L. & - & 0.0 & 0.1 & 0.1 & 0.1 & 0.0 & - \\
\hline Sonchus arvensis L. & 0.1 & - & 0.4 & 0.0 & 0.4 & - & - \\
\hline Taraxacum officinale F. H. Wigg. & 0.2 & 0.2 & 0.1 & 0.1 & 0.1 & 0.2 & 0.1 \\
\hline Total number of species & 23 & 23 & 28 & 22 & 28 & 23 & 22 \\
\hline
\end{tabular}

* A: control treatment; B: white mustard; C: lacy phacelia; D: narrow-leaf lupin + field pea

** a: mechanical weed control; b: mechanical and chemical weed control; c: chemical weed control

$* * * 0.0$ : the species was found in an amount of $<0.1$

Table 5

Dry weight yield of cover crop in $\mathrm{t} \times \mathrm{ha}^{-1}$ (mean for 2008-2010)

\begin{tabular}{cccc}
\hline Year & White mustard & Lacy phacelia & Legume mixture \\
\hline 2008 & 3.35 & 2.52 & 2.47 \\
2009 & 3.36 & 2.30 & 2.63 \\
2010 & 3.67 & 2.15 & 3.24 \\
\hline Mean & 3.46 & 2.32 & 2.78 \\
\hline
\end{tabular}


Table 6

Coefficients of correlation $(r)$ between cover crop dry weight and dry weight of weeds in the spring barley crop (mean for 2009-2011)

\begin{tabular}{lcccc}
\hline \multicolumn{1}{c}{ Weed control method } & White mustard & Lacy phacelia & Legume mixture & Mean \\
\hline Mechanical & -0.06 & 0.31 & 0.22 & 0.15 \\
Mechanical and chemical & -0.21 & -0.29 & $-0.51^{*}$ & -0.33 \\
Chemical & $-0.56^{*}$ & -0.11 & -0.30 & -0.32 \\
\hline Mean & -0.27 & -0.03 & -0.19 & - \\
\hline "significant correlation coefficient $(0.05)$ & & & \\
\hline
\end{tabular}

Table 7

Coefficients of correlation $(r)$ between cover crop dry weight and number of weeds in the spring barley crop (mean for 2009-2011)

\begin{tabular}{lcccc}
\hline \multicolumn{1}{c}{ Weed control method } & White mustard & Lacy phacelia & Legume mixture & Mean \\
\hline Mechanical & -0.02 & 0.21 & 0.26 & 0.15 \\
Mechanical and chemical & -0.37 & -0.08 & -0.32 & -0.25 \\
Chemical & -0.25 & -0.10 & -0.28 & -0.21 \\
\hline Mean & -0.21 & 0.01 & -0.11 & - \\
\hline "significant correlation coefficient (0.05) & & & \\
\hline
\end{tabular}

\section{DISCUSSION}

The study results presented in this paper show that the ploughed-in stubble crops did not reduce significantly the number of weeds in the spring barley crop. The study only found a trend towards its decrease after the white mustard cover crop compared to the treatment without the regenerating crop. $\mathrm{M} \mathrm{a} \mathrm{e} \mathrm{cka}$ et al. [7] obtained opposite results; according to these authors, the incorporation of the biomass of white mustard and oat/pea cover crops reduced the numbers of weeds in a barley crop by 20-25\% compared to the treatment without cover crop.

The present experiment proved that the air-dry weight of weeds was reduced after the white mustard and lupin/pea mixed cover crops had been ploughed under. The results of the studies of $\mathrm{Gaw}$ ę a [8], Dworakowski [12] and Kwiatkowski [13] also confirm the positive role of a white mustard cover crop in reducing weed weight. According to Oles zek et al. [14], a major role in reducing weed infestation is attributed to species of the family Brassicacae, since they inhibit the germination and then development of other plants due to biologically active substances contained in them. In the opinion of these authors, the allelopathic potential is manifested mainly in dead stems and leaves and it is greater when plant debris is incorporated into the soil.

In this experiment, mechanical weed removal involving only double harrowing proved to be ineffective in reducing the number and dry weight of weeds in the spring barley crop. Likewise, $\mathrm{K}$ w i a t k o w s k i [4] showed that intensive weed control caused a nearly threefold decrease in the number of weeds and a sevenfold decrease in weed weight compared to the treatments with extensive weed control (without using herbicides). A d a miak and Stępi eń [15] found that weed management in a barley monoculture using only mechanical methods was ineffective and additionally it promoted compensation of some species, such as Veronica arvensis, Capsella bursa-pastoris, Cirsium arvense, and Equisetum arvense.

K w i a tk ow ski [4] observed a reducing effect of Westerwolds ryegrass and white mustard cover crops on the number of weed species in a spring barley crop. The present experiment did not show the number of weed species to be reduced under the influence of ploughed-in stubble crops, but it found an increase in the number of weed species after the lacy phacelia cover crop.

The present study observed a significant reduction in the numbers of the dominant species Avena fat$u a$ under the conditions of chemical as well as chemical and mechanical weed control. In the opinion of some authors [16-18], herbicide application generally reduces the number of dominant weed species in a cereal crop. However, in a several-year-old monoculture the use of chemical agents can enhance the dominance, and in the long run also compensation, of some weeds, such as Galium aparine, Viola arvensis, Avena fatua, and Echinochloa crus-galli, as a result of their greater resistance to herbicides. 
According to $\mathrm{M} \mathrm{u} \mathrm{r}$ a w a et al. [19], the number and weight of weeds in a crop are reduced primarily through successful cover crops that produce a lot of biomass (legumes, oilseed rape, mustard). This was confirmed in the present study by the decrease in the number of weeds and the reduction in weed dry weight in the treatment with the stubble crop with the largest biomass (white mustard). The studies of many authors show a decrease in the number of weeds with an increase in the amount of biomass of cover crops that are ploughed back into the soil or left on the field surface for the winter period $[5,9,14,20]$.

\section{CONCLUSIONS}

1. The stubble crops did not reduce the number of weeds in the spring barley crop.

2. The ploughed-in biomass of white mustard and mixture of narrow-leaf lupin and field pea effectively reduced the air-dry weight of weeds at the beginning of the stem elongation stage of spring barley.

3. The highest number and dry weight of weeds were found under the conditions of mechanical weed control.

4. The stubble crops reduced the occurrence of Avena fatua in the spring barley crop.

5. Chemical as well as chemical and mechanical weed control significantly reduced the number of Avena fatua individuals compared to the treatment where only double harrowing was used for weed control.

6. The air-dry weight of weeds in the spring barley crop is significantly reduced with an increase in cover crop biomass that is ploughed under.

\section{Acknowledgements}

Research supported by the Ministry of Science and Higher Education of Poland as part of the statutory activities of the Department of Herbology and Plant Cultivation Techniques, University of Life Sciences in Lublin.

\section{Authors' contributions}

The following declarations about authors' contributions to the research have been made: conduct of the research, processing of results: DG; development of methodology and scientific oversight of the experiment: MW; statistical analysis of results: $\mathrm{CK}$.

\section{REFERENCES}

1. Johnston AE. The value of long-term experiments in agricultural, ecological and environmental research. Adv Agron. 1997;59:291-333. http://dx.doi.org/10.1016/S00652113(08)60057-7
2. Blecharczyk A, Małecka I, Pudełko J. Reakcja roślin na monokulturę $\mathrm{w}$ wieloletnim doświadczeniu w Brodach [Crop response of continuous cropping in Brody (Poland) long-term experiment]. Fragm Agron. 2005; 2(86): 20-29.

3. Buczyński G, Marks M. Zachwaszczenie i plonowanie jęczmienia jarego w płodozmianie i monokulturze [Spring barley weed infestation and yield in crop rotation and monoculture]. Zesz Probl Post Nauk Rol. 2003; 490: 41-47.

4. Kwiatkowski C. Studia nad plonowaniem jęczmienia jarego nagoziarnistego i oplewionego w płodozmianie i monokulturze [Studies on the yielding of naked and husked spring barley in crop rotation and monoculture]. Lublin: University of Life Sciences in Lublin Press; 2009. (vol 336).

5. Teasdale JR, Beste CE, Potts WE. Response of weeds to tillage and cover crop residue. Weed Sci. 1991; 39(2): 195-199.

6. Hauggaard-Nielsen H, Ambus P, Jensen E S . Interspecific competition, $\mathrm{N}$ use and interference with weeds in pea-barley intercropping. Field Crops Res. 2001; 70(2): 101-109. http://dx.doi.org/10.1016/S0378-4290(01) 00126-5

7. Małecka I, Blecharczyk A, Sawinska Z.Zachwaszczenie jęczmienia jarego w zależności od systemów uprawy roli i roślin mulczujących [Response of weed community in spring barley to tillage systems and cover crop mulches]. Zesz Probl Post Nauk Rol. 2003; 490: 163-169.

8. Gawęda D. Wpływ międzyplonów ścierniskowych na zachwaszczenie pszenicy jarej uprawianej w monokulturze [The influence of stubble crops on weed infestation of spring wheat grown in monoculture]. Ann UMCS Sec E. 2009; 64(3): 21-28.

9. Duer I. Wpływ międzyplonu ścierniskowego na plonowanie i zachwaszczenie jęczmienia jarego [Effect of catch crops on yield and weed infestation of spring barley]. Fragm Agron. 1994; 11(4): 36-45.

10. Marshall EJP, Brown VK, Boatman ND, Lutman PJW, Squire GR, Ward LK. The role of weeds in supporting biological diversity within crop fields. Weed Res. 2003; 43(2): 77-89. http://dx.doi.org/10. 1046/j.1365-3180.2003.00326.x

11. Kuś J, Jończyk K. Wpływ międzyplonów i sposobu uprawy roli na plonowanie roślin i zawartość azotu mineralnego w glebie [The effect of intercrops and the method of its cultivation on crop yielding and content of mineral nitrogen in soil]. Rocz Nauk Rol. 1999; 114(3-4): 83-95.

12. Dworakowski T. Działanie międzyplonu ścierniskowego w ogniwie zmianowania zboża ozime - zboża jare [The effect of a cover crop in crop rotation of winter cereals - spring cereals]. Fragm Agron. 1998;15(3):90-99.

13. Kwiatkowski C. Wpływ międzyplonu na plonowanie i zachwaszczenie jęczmienia jarego uprawianego w monokulturze [The effect of intercrops on yields and weed infestation of spring barley cultivated in monoculture]. Ann UMCS Sec E. 2004; 59(2): 809-815. 
14. Oleszek W, Ascard J, Johansson H. Brassicacae jako rośliny alternatywne umożliwiające kontrolę zachwaszczenia w rolnictwie zachowawczym [Brassicacae as alternative plants for weed control in sustainable agriculture]. Fragm Agron. 1994; 11(4): 5-19.

15. Adamiak J, Stępień A. Efektywność bronowania $w$ regulacji zachwaszczenia jęczmienia ozimego [The efficiency of harrowing in the regulation of winter barley infestation]. Prog Plant Prot. Post Ochr Rośl. 2003; 43(2): 506-509.

16. Adamiak E, Adamiak J, Stępień A. Wpływ następstwa roślin i stosowania herbicydów na zachwaszczenie jęczmienia jarego [Effect of crop sequence and herbicides application on weed infestation of spring barley]. Ann UMCS Sec E Supp. 2000; 55: 9-15.

17. Domaradzki K, Rola H. Wpływ długoletniej uprawy roślin zbożowych na dynamikę zachwaszczenia pola [The influence of long-term cultivation of cereals on weed infestation dynamic]. Prog Plant Prot. Post Ochr Rośl. 2002; 42(1): 228-233.

18. Heller K, Adamczewski K. Zmiany w zachwaszczeniu wywołane zmianami w agrotechnice roślin i zmianami klimatycznymi [Alternation in weed communities caused by changes in cultivation technology and climatic patterns]. Prog Plant Prot. Post Ochr Rośl. 2002; 42(1): 349-357.

19. Murawa D, Pykało I, B anaszkiewicz T.Kompleksowa ocena chwastobójcza substancji aktywnych w gorczycy białej (Sinapis alba L.) [The complex estimation of herbicidal activity of some chemicals applied in white mustard (Sinapis alba L.)]. Rośliny Oleiste XXV. 2004; 25: 521-531.

20. Akemo MC, Regnier EE, Bennett MA. Weed suppression in spring-sown rye (Secale cereale) - pea (Pisum sativum) cover crop mixes. Weed Technol. 2000; 14(3): 545-549. http://dx.doi.org/10.1614/0890-037X(2000) 014[0545:WSISSR]2.0.CO;2

\section{Zachwaszczenie \\ jęczmienia jarego (Hordeum vulgare $\mathrm{L}$.) w zależności od międzyplonu i sposobu odchwaszczania}

\section{Streszczenie}

W trzyletnich badaniach polowych oceniano wpływ wybranych międzyplonów ścierniskowych i sposobu odchwaszczania na skład gatunkowy, liczbę oraz powietrznie suchą masę chwastów w łanie jęczmienia jarego uprawianego w krótkotrwałej monokulturze. Badania prowadzono w latach 2009-2011 w Gospodarstwie Doświadczalnym Uhrusk, na rędzinie mieszanej zaliczanej do kompleksu żytniego bardzo dobrego. Uwzględniono w nich przyorywane corocznie międzyplony ścierniskowe (bez międzyplonów - obiekt kontrolny, gorczyca biała, facelia błękitna, mieszanka strączkowych - łubin wąskolistny + groch siewny pastewny) oraz 3 sposoby odchwaszczania jęczmienia jarego (mechaniczny, mechaniczno-chemiczny i chemiczny). W łanie jęczmienia jarego wysianego po międzyplonach ścierniskowych najliczniej występującym gatunkiem chwastów był Veronica persica. Wszystkie międzyplony ograniczyły liczbę dominującego na obiekcie kontrolnym Avena fatua. Chemiczny i mechaniczno-chemiczny sposób pielęgnacji łanu w znacznym stopniu ograniczyły liczbę Avena fatua względem obiektu odchwaszczanego wyłącznie przy pomocy 2-krotnego bronowania. Międzyplony ścierniskowe nie ograniczyły zachwaszczenia jęczmienia jarego. W porównaniu do obiektu kontrolnego powietrznie suchą masę chwastów ograniczyło przyoranie gorczycy białej i mieszanki roślin strączkowych, odpowiednio o 49,1 i 22,7\%. Mechaniczna walka z chwastami okazała się mniej skuteczna w redukcji liczby i powietrznie suchej masy chwastów w porównaniu do pozostałych sposobów pielęgnacji. Stwierdzono istotną ujemną korelację między powietrznie suchą masą chwastów w łanie jęczmienia jarego a powietrznie suchą masą przyorywanego międzyplonu z gorczycy białej, w warunkach chemicznego sposobu odchwaszczania oraz mieszanki roślin strączkowych gdy zastosowano kompleksową mechaniczno-chemiczną pielęgnację łanu.

Handling Editor: Elżbieta Weryszko-Chmielewska

This is an Open Access digital version of the article distributed under the terms of the Creative Commons Attribution 3.0 License (creativecommons.org/licenses/by/3.0/), which permits redistribution, commercial and non-commercial, provided that the article is properly cited.

(CThe Author(s) 2014 Published by Polish Botanical Society 